\title{
PENGARUH KERAGAMAAN PRODUK DAN KUALITAS PELAYANAN TERHADAP KEPUASAN KONSUMEN DI HEPI SWALAYAN KEFAMENANU
}

\author{
Yesus Armiro Korbaffo ${ }^{1}$ \\ armirokorbaffo@gmail.com \\ Didimus Opat ${ }^{2}$ \\ Prodi. Manajemen Fakultas Ekonomi dan Bisnis UNIMOR
}

\begin{abstract}
ABSTRAK
Tujuan dalam penelitian ini adalah: Untuk mengetahui pengaruh variabel Keragaman Produk dan, Kualitas Pelayanan terhadap Kepuasan Konsumenpada HEPI Swalayan Kefamenanu.Hasil Analisis Inferensial diketahui Hasil analisis menunjukkan pengaruh yang signifikan antara variabel keragaman produk terhadap variabel kepuasan konsumen di Hepi Swalayan Kefamenanu.

Untuk itu, penetapan strategi keragaman sebuah produk harus mempertimbangkan kedalaman dan lebar, kualitas produk dan ketersediaan produk, yang dapat berpengaruh pada kepuasan konsumen di Hepi Swalayan Kefamenanu.Hasil analisis menunjukkan pengaruh yang signifikan antara variabel kualitas pelayanan terhadap variabel kepuasan konsumen diHepi Swalayan Kefamenanu.

Untuk itu dalam mencapai kualitas pelayanan yang baik harus memperhatikan pemenuhan kebutuhan konsumen, pemenuhan keinginan konsumen, ketepatan memberi informasi pelayanan. Yang sangat berpengaruh terhadap kepuasan konsumen di Hepi Swalayan Kefamenanu. Hasil analisis menunjukkan pengaruh yang signifikan antara variabel keragaman produk dan variabel kualitas pelayanan terhadap variabel kepuasan konsumen di Hepi Swalayan Kefamenanu. Untuk itu, dalam penetapan strategi keragaman produk dan kualitas pelayanan perlu mempertimbangkan dan meningkatkan ketersediaan produk, kualitas produk, kebutuhan konsumen dan keinginan konsumen agar adanya kepuasan konsumen di Hepi Swalayan Kefamenanu
\end{abstract}

Kata kunci : Kepuasan, Keragaman dan Kualitas 


\section{PENDAHULUAN}

Dewasa ini perhatian terhadap kepuasan konsumen atau ketidakpuasan konsumen semakin besar. Persaingan yang semakin ketat khusunya untuk bisnis ritel, dimana banyak produsen yang terlibat dalam pemenuhan kebutuhan dan keinginan konsumen, menyebabkan setiap perusahaan ritel harus menempatkan orientasi kepuasan pelanggan sebagai tujuan utama dan diyakini sebagai kunci utama untuk memenangkan persaingan adalah memberikan nilai kepuasan kepada konsumen melalui penyampaian produk dan jasa dengan harga bersaing.

Perubahan makro seperti krisis ekonomi membuktikan bahwa sektor rill yang meliputi sektor perdagangan dan jasa termasuk didalamnya bisnis ritel. Hal ini mengakibatkan banyak bermunculan bisnis dibidang ritel sehingga persaingan tidak bisa dihindari. Kepuasan konsumen adalah faktor yang menentukan dalam strategi pemasaran perusahaan yang merupakan pertahanan paling baik untuk menghadapi persaingan yang sangat ketat yang menyebabkan perusahaan harus menempatkan pada kepuasan konsumen sebagai tujuan utama, sehingga ini menjadi salah satu penentu suksesnya pemasaran. Kesetiaan konsumen agar tidak hilang maka perlu mengetahui kelebihan dan kekurangan dalam strategi bauran pemasaran eceran dan kualitas pelayanan sebagai analisis agar dapat berorientasi pada kepuasan konsumen. Kepuasan menerut Kotler(2004) adalah tingkat perasaan seseorang setelah membandingkan kinerja (hasil) yang dia rasakan dengan harapannya. Namun, mereka yang merasa sangat puas tidak akan terlalu mudah untuk mengubah pilihan mereka karena kepuasan tinggi akan membuat emosional terikat terhadap produk tertentu (Kotler 2004).

Salah satu unsur kunci dalam persaingan diantara bisnis eceran adalah ragam produk yang disediakan oleh pengecer. Oleh karena itu, pengecer harus membuat keputusan yang tepat mengenai keragaman produk yang dijual, karena dengan adanya macam-macam produk dalam arti produk yang lengkap mulai dari merek, ukuran, kualitas dan ketersediaan produk setiap saat. Dengan hal tersebut maka akan memudahkan konsumen dalam memilih dan membeli berbagai macam produk sesuai dengan keinginan mereka. Sesuatu yang diinginkan oleh konsumen adalah bagaimana cara untuk mendapatkan barang-barang yang dibutuhkan serta menyediakan beraneka ragam produk dan alternatif pilihan, harga yang bersaing, pelayanan dan fasilitas yang memuaskan serta suasana berbelanja yang nyaman yang semuanya terdapat dalam satu toko seperti swalayan.

Disamping memperhatikan keragaman produk, perusahaan yang bergerak dibidang retail harus juga berupaya untuk memberikan pelayanan yang baik, sebab pelayanan yang berkualitas merupakan salah satu cara untuk menarik dan mempertahankan konsumen. Pelayanan harus diperhatikan karena dalam memilih suatu produk atau jasa konsumen selalu merasa nilai yang dirasakan. Apabila konsumen merasa nilai yang dirasakan lebih tinggi dari apa yang diharapkan maka konsumen akan merasa puas.

Strategi untuk memuaskan konsumen antara lain dengan meningkatkan kualitas pelayanan, kepuasan konsumen sangat penting untuk sebuah perusahaan, dan itu merupakan faktor pertimbangan yang kuat untuk membuat kebijakan selanjutnya.Kualitas pelayanan juga mempengaruhi atau berhubungan dengan 
keputusan konsumen untuk memilihdengankata lain kualitas pelayanan adalah sebuah pertimbangan apakah konsumen tetap setia atau berpaling memilih yang lain. Jika pelanggan merasa bahwa dia menerima pelayanan berkualitas, maka dia akan merasa puas. Pelanggan lebih memilih perusahaan-perusahaan bonafit daripada perusahaan lainya. Pada akhirnya konsumen akan membayar lebih untuk sebuah kualitas.

Implikasi Futher dari perilaku ini adalah penguatan hubungan atau koneksi antara konsumen dan produsen. Sebaliknya, jika layanan dianggap kurang memuaskan atau rendah, maka keputusan konsumen akan menjadi kurang baik seperti mengeluh, beralih ke perusahaan lain, pengeluaran kurang dan akhirnya melemahkan hubungan antara pelanggan dan perusahaan (Zeithaml et.al, 2001). MenurutTjiptono (2000) pelayanan yang baik dapat dijadikan sebagai modal untuk menarik minat konsumen bagi perusahaan jasa tentu cukup sulit untuk mendapatkan standar pelayanan yang samadimata konsumen. Hal ini menurut kejelian pengelolaan SDM yang dimiliki agar kinerjanya optimum dalam memuaskan konsumen (Lupiyoadi 2006). Oleh karena itu pelayanan yang baik dapat dijadikan modal untuk menarik minat konsumen karena kualitas pelayanan dapat menentukan kepuasan dan keinginan menggunakan lagi jasa tersebut (loyalitas konsumen).

Dewasa ini pasar swalayan semakin banyak dibuka diberbagai tempat baik di kota besar maupun di kota kecil. Khususnya di Kefamenanu, kehadiran pasar swalayan merupakan tuntutan perubahan gaya hidup masyarakat kota. Kondisi semacam ini mencerminkan suatu fenomena yang terjadi bahwa masyarakat menjadi semakin kritis dalam memilih obyek pembelanjaan. Sifat kritis tersebut dicirikan antara lain masyarakat menginginkan barang selengkap mungkin, harga yang murah, produk yang berkualitas, pelayanan dan fasilitas yang memuaskan yang semuanya terdapat dalam satu toko yaitu pasar swalayan.

Semakin meningkatnya kebutuhan manusia dalam memenuhi kebutuhan hidup sehari-hari yang didapatkan melalui kegiatan berbelanja di toko swalayan memiliki tujuan untuk mendapatkan kepuasan tersendiri atas aktivitas yang dilaksanakan konsumen. Hal-hal yang akan ditawarkan yang notabene bukan hanya dalam bentuk barang harus memiliki kelebihan-kelebihan khusus yang bersifat positif dibandingkan dengan penawaran usaha ritel lainnya, maka konsumen tetap setia. Dalam mempertahankan konsumen, perusahaan harus dapat memberikan kepuasan yang maksimal dalam memuaskan konsumennya. Adapun kepuasan konsumen dapat terjadi apabila harapan benar-benar terwujud demikian pula sebaliknya, jika pelanggan merasa puas, maka mereka akan kembali membeli produk dan membicarakan hal tersebut kepada orang lain secara menguntungkan.

Bertambahnya jenis-jenis retail baru dalam bentuk swalayan seperti minimarket, supermarket dan hypermarket akan memicu persaingan yang semakin ketat. Apalagi dengan kehadiran retail asing pasti akan membuat persaingan di dunia retail tampaak semakin kompetitif sehingga para retailer lokal dituntut untuk lebih adaptif dalam mengadopsi konsep-konsep baru dibidang retail, menyangkut konsep modern merchandising, category manangement, modern retail supply chain, pricing technique, promotion and marketing strategy, supplier relationship and negotiation technique (Sujana, 2005). 
Melihat potensi pasar di Kabupaten Timor Tengah Utara yang cukup prospektif dengan kehadiaran Universitas Timor (UNIMOR) yang memicu bertambahnya penduduk setiap tahun membuat para pemain bisnis retail semakin antusias untuk masuk ke Kefamenanu. Belum lagi jika dilihat dari perputaran uang di bisnis retail memang luar biasa. Pada tahun 2004, Asosiasi Pengusaha Ritel Indonesia (Aprindo) menghitung market size pasar retail senilai Rp. 330 trilyun (www.swa.co.id).

HEPI Swalayan merupakan salah satu usaha ritel yang berada di pusat Kefamenanu yang menjual dan menyediakan berbagai macam jenis produk untuk ditawarkan mulai dari produk makanan, minuman, serta berbagai macam produk kebutuhan rumah tangga dan juga menyediakn produk mainan untuk anak-anak serta produk untuk remaja seperti produk kecantikan, parfum, serta aksesoris lainnya yang beroperasi atas dasar konsumen melayani diri sendiri; dimana pembeli ambil sendiri barang yang dibutuhkan. Hal ini sejalan dengan pandangan Suud.M(1994) bahwa pasar swalayan adalah tipe toko eceran yang bergerak dalam kebutuhan makanan dan minuman serta kebuthan rumah tangga lainnya yang beroperasi dalam swalayan dengan pelayanan yang sedikit mungkin, penawaran harga barang yang menawan, dan biasanya ada tempat parkir yang luas.

Selain HEPI Swalayan masih ada beberapa toko swalayan lainnya seperti Jabal Mart, Tulip Swalayan, Jaya Swalayan, Lay Swalayan, Jabalsur Toserba ataupun pusat-pusat perbelanjaan lainya. Dengan adanya potensi pasar tersebut, tidak menutup kemungkinan berdatangan peritel global yang akan menambah suasana persaingan bisnis retail semkain ketat. Disamping itu, pesaing swalayan tidak hanya toko-toko yang menghiasi sepanjang jalan protokol tetapi juga pasar tradisional yang telah lama ada yang merupakan tantangan bagi HEPI Swalayan.

Namun belakangan ini bisnis retail makin marak. Banyak toko swalayan lainnya seperti Jabal Mart, Tulip Swalayan, Jaya Swalayan, Lay Swalayan, Jabalsur Toserba ataupun pusat-pusat perbelanjaan lainya yang merupakan pesaing bagi HEPI Swalayan. Hal ini harus diwapadai oleh HEPI Swalayan Kefamenanu jika ingin mempertahankan pelanggannya dan mendapatkan pelanggan baru. Untuk itu HEPI Swalayan harus berfokus kepada kepuasan pelanggan karena kepuasan pelanggan merupakan sasaran pemasaran.

Dari beberapa uraian latar belakang di atas dapat diidentifikasibahwa Keragaman produk dan kualitas pelayanan merupakan hal yang sangat mempengaruhi kepuasan

konsumen karena dengan adanya macam-macam produk dalam arti produk yang lengkap mulai dari merek, ukuran akan memudahkan konsumen dalam memilih dan membeli berbagai macam produk sesuai dengan keinginan mereka dan apabila pelanggan merasa bahwa dia menerima pelayanan berkualitas, maka kepuasan konsumen akan tercapai.

Bertolak dari latar belakang dan tampilan hasil survey awal tersebut diatas, maka peneliti tertarik untuk mengembangkan penelitian lebih lanjut dengan judul "Pengaruh Keragamaan Produk dan Kualitas Pelayanan terhadap Kepuasan Konsumen di HEPI Swalayan Kefamenanu" 


\section{METODE}

Pendekatan yang digunakan dalam penelitian ini adalah pendekatan kuantitatif. Penelitian ini mengunakan sampling jenuh yang merupakan teknik penentuan sampel bila semua anggota populasi digunakan sebagai sampel, sehingga sampel berjumlah 60 orang.Penelitian ini dilaksanakan di HEPI Swalayan Kefamenanu, Kabupaten Timor Tengah Utara (TTU).

Pengumpulan data dilakukan dengan teknik Kuesioner, Observasi dan Dokumentasi.Data hasil penyebaran kuesioner untuk selanjutnya dianalisa menggunakan analisis deskriptif, selain itu juga dinalisis menggunakan software SPSS. Analisa yang dilakukan adalah uji validitas, uji realibilitas, dan regresi linear berganda.

\section{PEMBAHASAN}

Untuk mengetahui pengaruh variabel keragaman produk $\left(\mathrm{X}_{1}\right)$ dan kualitas pelayanan $\left(\mathrm{X}_{2}\right)$ terhadap variabel kepuasan konsumen $(\mathrm{Y})$ dapat digunakan alat analisis regresi linear berganda dengan bantuan program SSPS for Windows 16.0. Besarnya nilai regresi antara keragaman produk $\left(\mathrm{X}_{1}\right)$ dan kualitas pelayanan $\left(\mathrm{X}_{2}\right)$ terhadap variabel kepuasan konsumen $(\mathrm{Y})$ adalah sebagai berikut:

$$
\begin{aligned}
& \mathrm{Y}=\alpha+\mathrm{b}_{1}\left(\mathrm{X}_{1}\right)+\mathrm{b}_{2}\left(\mathrm{X}_{2}\right)+\varepsilon \mathrm{i} \\
& \mathrm{Y}=1,457+0,220\left(\mathrm{X}_{1}\right)+0,580\left(\mathrm{X}_{2}\right)+\varepsilon \mathrm{i}
\end{aligned}
$$

Berdasarkan model regresi linear berganda diatas, maka dapat dijelaskan:

1) Konstanta sebesar 1,457; artinya jika variabel keragaman produk $\left(\mathrm{X}_{1}\right)$ dan variabel kualitas pelayanan $\left(\mathrm{X}_{2}\right)$ tidak berubah, maka variabel kepuasan konsumen (Y) nilainya sebesar 1,457.

2) Koefisien regresi variabel keragaman produk $\left(X_{1}\right)$ sebesar 0,220 ; artinya jika variabel independen lain nilainya tetap dan variabel keragaman produk $\left(\mathrm{X}_{1}\right)$ bertambah satu satuan maka variabel kepuasan konsumen (Y) akan mengalami peningkatan sebesar 0,220. Koefisien bernilai positif artinya terjadi pengaruh positif antara variabel keragaman produk $\left(\mathrm{X}_{1}\right)$ dan variabel kepuasan konsumen $(\mathrm{Y})$. Semakin baik variabel keragaman produk $\left(\mathrm{X}_{1}\right)$ maka semakin meningkat variabel kepuasan konsumen (Y).

3) Koefisien regresi variabel kualitas pelayanan $\left(\mathrm{X}_{2}\right)$ sebesar 0,580; artinya jika variabel independen lain nilainya tetap dan variabel kualitas pelayanan $\left(\mathrm{X}_{2}\right)$ mengalami kenaikan satu satuan maka variabel kepuasan konsumen (Y) akan mengalami peningkatan sebesar 0,580. Koefisien bernilai positif artinya terjadi pengaruh positif antara variabelkualitas produk $\left(\mathrm{X}_{2}\right)$ dan variabel kepuasan konsumen (Y).Semakin baik variabel kualitas pelayanan $\left(\mathrm{X}_{2}\right)$ maka semakin meningkat variabel kepuasan konsumen $(\mathrm{Y})$.

Besarnya nilai koefisien regresi $(\mathrm{R})$ variabel keragaman produk $\left(\mathrm{X}_{1}\right)$ dan variabel kualitas pelayanan $\left(\mathrm{X}_{2}\right)$ terhadap variabel kepuasan konsumen (Y) sebesar 0,773;yang artinya bahwa terdapat pengaruh yang kuat antara variabel keragaman produk $\left(\mathrm{X}_{1}\right)$ dan variabel kualitas pelayanan $\left(\mathrm{X}_{2}\right)$ terhadap variabel kepuasan konsumen (Y). 
Koefisien determinanasi (Adjusted $R$ Squere) menjelaskan tentang nilai variasi variabel kepuasan konsumen $(Y)$ ditentukan oleh variabel keragaman produk $\left(\mathrm{X}_{1}\right)$ dan variabel kualitas pelayanan $\left(\mathrm{X}_{2}\right)$. Dari hasil analisis determinasi (Adjusted $R$ Squere) diperoleh nilai 0,597. Artinya bahwa besarnya variabel kepuasan konsumen $(\mathrm{Y})$ dipengaruhi oleh variabel keragaman produk $\left(\mathrm{X}_{1}\right)$ dan variabel kualitas pelayanan $\left(\mathrm{X}_{2}\right)$ sebesar 59,7\%, dan sisanya sebesar 40,3\% dipengaruhi oleh variabel $\mathrm{X}$ lain yang tidak dimasukkan dalam model penelitian ini.

Besarnya nilai $F_{\text {hitung }}$ yang diperoleh sebesar 31,081. Sedangkan $F_{\text {tabel }}$ dengan derajat kebebasan $\mathrm{df}=\mathrm{n}-2(45-2=43)$ pada signifikansi 0,05 diperoleh3,23. Dengan demikian maka nilai $F_{\text {hitung }}>$ dari nilai $F_{\text {tabel }}$ dimana 31,081 $>3,23$ maka ada pengaruh signifikan variabel keragaman produk $\left(\mathrm{X}_{1}\right)$ dan variabel kualitas pelayanan $\left(\mathrm{X}_{2}\right)$ terhadap variabel kepuasan konsumen $(\mathrm{Y}) \mathrm{di}$ Hepi Swalayan Kefamenanu.

\section{Koefisien Determinasi $\left(\mathbf{R}^{2}\right)$}

Nilai R yang diperoleh adalah sebesar 0,773 Ini berarti bahwa hubungan antara variabel keragaman produk $\left(\mathrm{X}_{1}\right)$ dan kualitas pelayanan $\left(\mathrm{X}_{2}\right)$ terhadap kepuasan konsumen (Y) pada Hepi Swalayan Kefamenanu adalah sangat kuat.

Koefisien determinasi $\left(\mathrm{R}^{2}\right)$ menjelaskan tentang kontribusi variabelvariabel independen terhadap variabel kepuasan konsumen (Y) yang diperlihatkan (adjusted $R$ square). Dari hasil analisis koefisien determinasi $\left(\mathrm{R}^{2}\right)$ dipeorleh nilai sebesar 0,597. Artinya, bahwa besarnya variabel keragaman produk $\left(\mathrm{X}_{1}\right)$ dan variabel kualitas pelayanan $\left(\mathrm{X}_{2}\right)$ sebesar 59,7 \% dan sisanya sebesar $40,3 \%$ dipengaruhi variabel $\mathrm{X}$ lain yang tidak dimasukan dalam model penelitian ini.

\section{PENUTUP}

\section{Simpulan}

Berdasarkan pembahasan pada Bab sebelumnya, maka dapat disimpulkan sebagai berikut:

1. Hasil analisis menunjukkan pengaruh yang signifikan antara variabel keragaman produk $\left(\mathrm{X}_{1}\right)$ terhadap variabel kepuasan konsumen $(\mathrm{Y})$ di Hepi Swalayan Kefamenanu. Untuk itu, penetapan strategi keragaman sebuah produk harus mempertimbangkankedalaman dan lebar, kualitas produk dan ketersediaan produk, yang dapat berpengaruh pada kepuasan konsumen di Hepi Swalayan Kefamenanu.

2. Hasil analisis menunjukkan pengaruh yang signifikan antara variabel kualitas pelayanan $\left(\mathrm{X}_{2}\right)$ terhadap variabel kepuasan konsumen $(\mathrm{Y})$ diHepi Swalayan Kefamenanu. Untuk itu dalam mencapai kualitas pelayanan yang baik harus memperhatikan pemenuhan kebutuhan konsumen, pemenuhan keinginan konsumen, ketepatan memberi informasi pelayanan. Yang sangat berpengaruh terhadap kepuasan konsumen di Hepi Swalayan Kefamenanu.

3. Hasil analisis menunjukkan pengaruh yang signifikan antara variabel keragaman produk $\left(\mathrm{X}_{1}\right)$ dan variabel kualitas pelayanan $\left(\mathrm{X}_{2}\right)$ terhadap 
variabel kepuasan konsumen (Y) di Hepi Swalayan Kefamenanu. Untuk itu, dalam penetapan strategi keragaman produk dan kualitas pelayanan perlu mempertimbangkan dan meningkatkan ketersediaan produk, kualitas produk, kebutuhan konsumen dan keinginan konsumen agar adanya kepuasan konsumen di Hepi Swalayan Kefamenanu.

\section{Saran}

Berdasarkan kesimpulan dari hasil analisis data menggunakan regresi linear sederhana dan berganda bahwa ada pengaruh yang signifikan antara variabel keragaman produk $\left(\mathrm{X}_{1}\right)$ dan variabel kualitas pelayanan $\left(\mathrm{X}_{2}\right)$ terhadap variabel kepuasan konsumen $(\mathrm{Y})$ di Hepi Swalayan Kefamenanu, maka saran dari penulis adalah:

1. Memperhatikan strategi penetapan keragaman sebuah produk harus mempertimbangkankedalaman dan lebar, kualitas produk dan ketersediaan produk, yang dapat berpengaruh pada kepuasan konsumen di Hepi Swalayan Kefamenanu

2. Meningkatkan kualitas pelayanan harus memperhatikan pemenuhan kebutuhan konsumen, pemenuhan keinginan konsumen, ketepatan memberi informasi pelayanan. Yang sangat berpengaruh terhadap kepuasan konsumen di Hepi Swalayan Kefamenanu

3. Meningkatkan kepuasan konsumen perlu mempertimbangkan ketersediaan produk, kualitas produk, kebutuhan konsumen dan keinginan konsumen agar adanya kepuasan konsumen di Hepi Swalayan Kefamenanu. 


\section{DAFTAR PUSTAKA}

Ghozali, Imam (2007).AplikasiAnalisisMultivariate dengan Program SPSS.Semarang,BadanPenerbitUniversitasDiponegoro.

Kostas,N. Dervitsiotis (1948).Operations Management.International Student Edition,McGraw-Hill.

Kotler, Philip (2000). ManajemenPemasaran:EdisiMillenium.CetakanPertama. Jakarta :Penerbit PT IkrarMandiriAbdi.

Kotler, Philip \& Kevin Lane Keller (2007). .Manajemenpemasaran.edisiKeduabelas.Jakarta :Penerbit PT Indeks.

Malhotra, Naresh K. 2005. RisetPemasaran :PedekatanTerapan.EdisiEmpat (TerjemahanSolehRusyadi Mariam). Jakarta :Penerbit PT IndeksKelompokGramedia.

Nafanu, Sirilius (2012). StrategiMarketingMix.EdisiPertama.Yogjakarta: Penerbit Absolute Media.

Stanton, J. William and Futrell (1987).Fundamental of Marketing. New York: McGraw-Hill,Inc.

Sugiyono (2008).MetodePenelitianBisnis: PendekatanKuantitatif, Kualitatifdan Research \& Development. Bandung: PenerbitAlphabeta.

Triyono, Sigit (2006). SuksesTerpaduBisnisRetail.CetakanPertama Jakarta: PT. Elex Media Komputindo.

Woodside G, Frey L. Daly TM (1989). Linking Service Quality, C ustomerSatisfaction and Behavioral Intentionss.Journal of Health CareMarketing. Vol. 9.P .5-17.

Seran, Sirilius (2012). Metodoligi Penelitian Sosial dan Ekonomi. Cetakan kedua. Kupang : Penerbit Gita Kasih.

Cronim et. Al (2001). Some New Thogth on Conseptulizing 


\section{Lampiran}

\section{Uji}

Realibilitas

\begin{tabular}{|l|l|l|}
\hline \multicolumn{1}{|c|}{ Dimensi } & $\begin{array}{c}\text { Koefisien } \\
\text { Alpha }\end{array}$ & \multicolumn{1}{c|}{ Status } \\
\hline Variabel Keragaman Produk $\left(\mathrm{X}_{1}\right)$ & 0,833 & Reliabel dapat diterima \\
\hline Variabel Kualitas Pelayanan $\left(\mathrm{X}_{2}\right)$ & 0,870 & Reliabel dapat diterima \\
\hline Kepuasan Konsumen $(\mathrm{Y})$ & 0,881 & Reliabel dapat diterima \\
\hline
\end{tabular}

Uji Multikolianeritas

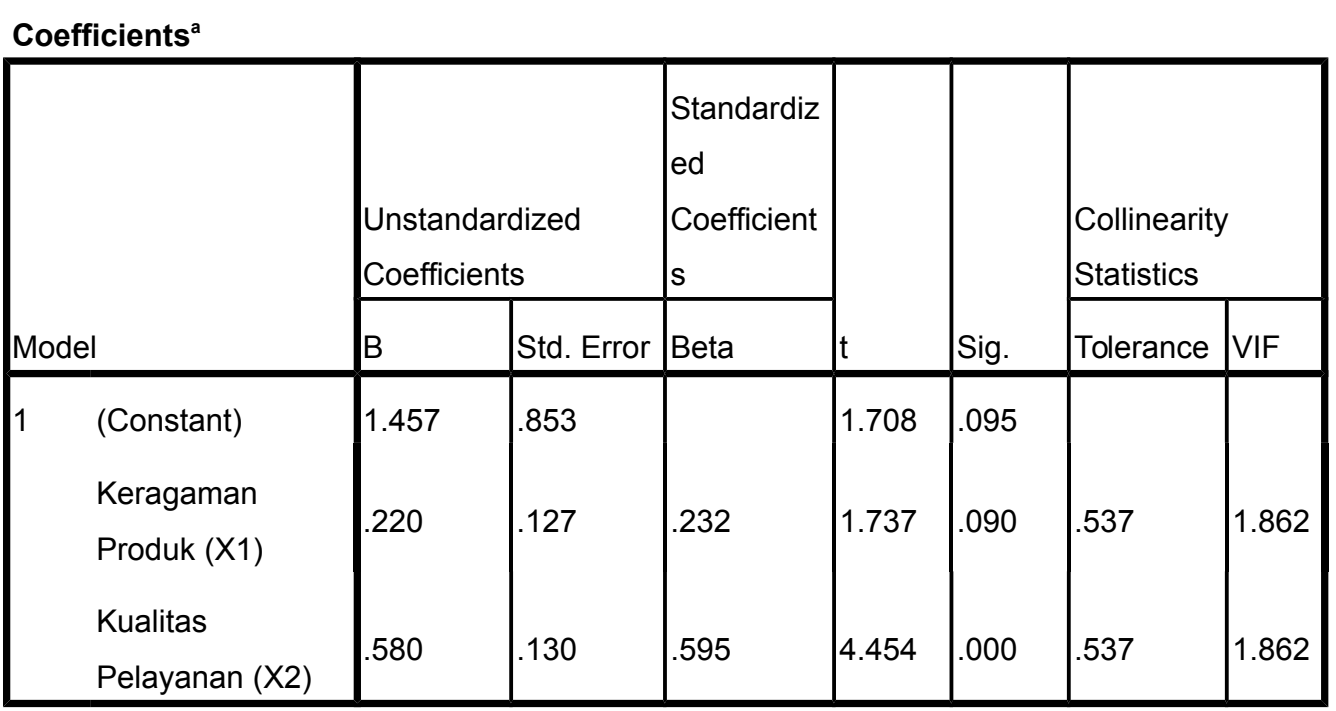

a. Dependent Variable: Kepuasan Konsumen

(Y)

Uji Normalitas

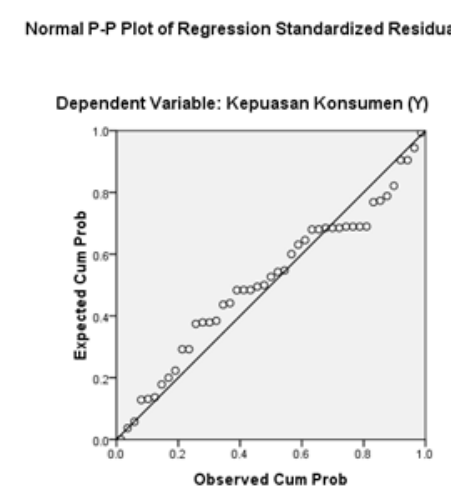




\section{Uji Autokorelasi}

Model Summary

\begin{tabular}{|l|l|l|l|l|l|}
\hline Model & $\mathrm{R}$ & $\mathrm{R}$ Square & $\begin{array}{l}\text { Adjusted } \\
\text { Square }\end{array}$ & $\begin{array}{l}\text { R } \\
\text { Std. Error of the } \\
\text { Estimate }\end{array}$ & Durbin-Watson \\
\hline 1 & $.773^{\mathrm{a}}$ & .597 & .578 & 1.49769 & 1.653 \\
\hline
\end{tabular}

a. Predictors: (Constant), Kualitas Pelayanan (X2), Keragaman Produk (X1)

b. Dependent Variable: Kepuasan Konsumen (Y)

\section{Uji Heterokesdatisitas}

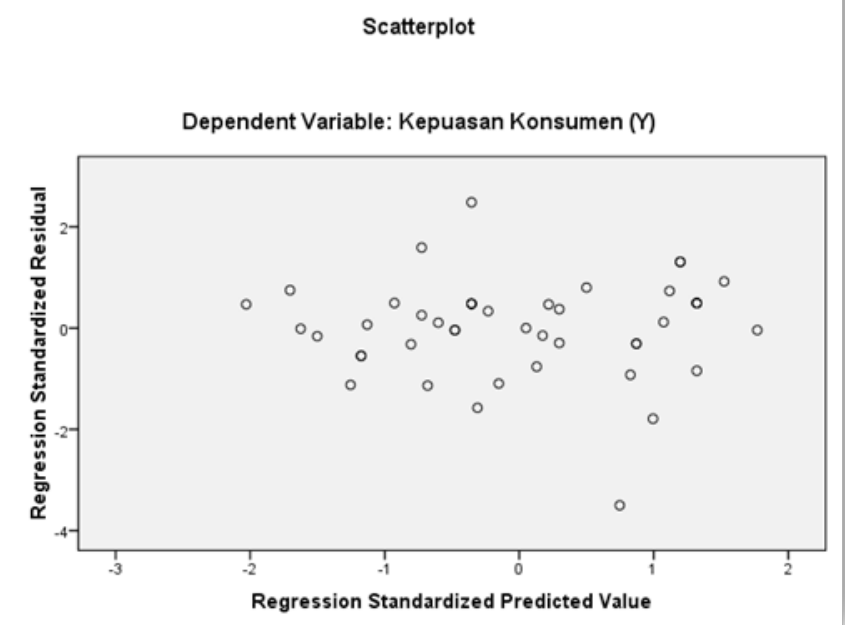

Uji Linearitas

\section{ANOVA Table}

\begin{tabular}{|c|c|c|c|c|c|c|c|}
\hline & & & $\begin{array}{l}\text { Sum of } \\
\text { Squares }\end{array}$ & df & $\begin{array}{l}\text { Mean } \\
\text { Square }\end{array}$ & $F$ & Sig. \\
\hline \multirow{5}{*}{$\begin{array}{l}\text { Kepuasan } \\
\text { Konsumen (Y) } \\
\text { Keragaman } \\
\text { Produk (X1) }\end{array}$} & \multirow{3}{*}{$\begin{aligned} & \text { Between } \\
& \text { * Groups }\end{aligned}$} & (Combined) & 116.371 & 9 & 12.930 & 3.859 & .002 \\
\hline & & Linearity & 94.942 & 1 & 94.942 & 28.335 & .000 \\
\hline & & Deviation from Linearity & 21.429 & 8 & 2.679 & .799 & .607 \\
\hline & \multicolumn{2}{|c|}{ Within Groups } & 117.274 & 35 & 3.351 & & \\
\hline & \multicolumn{2}{|l|}{ Total } & 233.644 & 44 & & & \\
\hline
\end{tabular}

